Wasterlain Sofia (Orcid ID: 0000-0003-2913-3037)

Ferreira Maria Teresa (Orcid ID: 0000-0002-2437-7780)

\title{
Enamel hypoplasia in African enslaved individuals from Valle da Gafaria, Lagos,
}

\section{Portugal $\left(15^{\text {th }}-17^{\text {th }}\right.$ centuries $)$}

Sofia N. Wasterlain ${ }^{1,2, *}$, Ana Isabel Rufino ${ }^{1}$, Liliana M.Carvalho ${ }^{2}$, Maria Teresa Ferreira ${ }^{1,2}$

${ }^{1}$ University of Coimbra, Research Centre for Anthropology and Health, Department of Life

Sciences, Calçada Martim de Freitas, 3000-456 Coimbra, Portugal

${ }^{2}$ University of Coimbra, Centre for Functional Ecology, Laboratory of Forensic Anthropology, Department of Life Sciences, Calçada Martim de Freitas, 3000-456 Coimbra, Portugal

Running head: Enamel hypoplasia in enslaved Africans

*Corresponding author:

Sofia N. Wasterlain

Departamento de Ciências da Vida, Calçada Martim de Freitas, 3000-456 Coimbra, Portugal

Telephone: +351239240717

E-mail address: sofiawas@ antrop.uc.pt

This article has been accepted for publication and undergone full peer review but has not been through the copyediting, typesetting, pagination and proofreading process which may lead to differences between this version and the Version of Record. Please cite this article as doi: 10.1002/oa.2917 


\begin{abstract}
Dental enamel hypoplasia, a defect of enamel formation, has been widely used for the investigation of growth disruptions in past populations, as it provides a permanent record of disturbances occurring during an individual's development. With the aim of recording changes in health status during development of the African enslaved individuals recovered from Valle da Gafaria, Lagos, Portugal $\left(15^{\text {th }}-17^{\text {th }}\right.$ centuries $)$, linear enamel hypoplastic defects were investigated in a sample of 78 individuals aged 12-40+ years old. Of the 744 anterior teeth present, $13.0 \%$ were not observable due to dental calculus, tooth wear or intentional modifications. In all, 647 teeth were macroscopically observed for the presence of dental enamel defects according to Goodman and Rose (1990), and Buikstra and Ubelaker (1994). The position of each defect on the crown was scored by measuring its distance to the cemento-enamel junction on the labial surface of the crown, being the age of occurrence of the physiological stress thereafter calculated according to Reid and Dean (2000, 2006). Of the 78 individuals, $89.7 \%$ had at least one defect. Of the 647 teeth, $63.5 \%$ presented at least one defect. The age of occurrence of the physiological stress ranged between 1.5 and 5.2 years of age, and the mean peak age was between 3.3 and 3.7 years. A previous study has found that the non-adult individuals of this skeletal assemblage died more frequently between 7 and 9 years. Although these two age-ranges may represent distinct sets of adverse factors, such as weaning and workload, respectively, they reinforce the idea that the Lagos's individuals experienced harsh living conditions during childhood.
\end{abstract}

Key Words: Developmental defects; teeth; slavery; Africa.

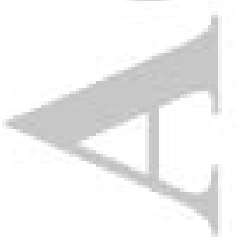




\section{Introduction}

Dental enamel hypoplasia is a surface defect of the tooth crown due to physiological insults during amelogenesis (Goodman and Rose, 1990). It develops as a consequence of an impairment of enamel matrix secretion, appearing as a deficiency in the thickness of the enamel (Goodman and Rose, 1990; Hillson, 2005; Witzel et al., 2006). Hypoplastic defects vary greatly in their macroscopic appearance depending on the intensity and duration of the insult and the corresponding reaction of the secretory; the number of secretory ameloblasts affected by the insult; the position of the affected ameloblasts along the corono-cervical tooth axis and the corresponding time elapsed from entering into the secretory stage; and the species- and tooth-specific geometry of crown growth (Hillson and Bond, 1997; Witzel et al., 2006, 2008). Three main types of hypoplastic defects are distinguished in humans: pit-type (focal reductions of enamel thickness of either isolated pits or groups of pits); furrow-type (furrows running horizontally around the tooth crown); and plane-type (extended areas of thinner than normal enamel) (Commission on Oral Health, 1982; Witzel et al., 2006). Their formation has been related to the intensity and duration of stress events, the number of affected ameloblasts, and their position along the forming tooth crown (Hillson and Bond, 1997; Witzel et al., 2006, 2008). According to Hillson and Bond (1997), the commonest type seen with the naked eye is the furrow-type (also referred as linear enamel hypoplasia - LEH), which is the most prominent expression of a continuum extending ever smaller, down to a microscopic disturbance to a single layer in the crown formation sequence.

Because of the inability of enamel to remodel or repair, enamel hypoplasia can provide a permanent record of disturbances occurring during an individual's development (Goodman and Rose, 1990; Skinner and Goodman, 1992). Given that the metabolic insult affects only the part of the tooth which is being formed, the hipoplasia's location on the crown surface can be converted into the age of its occurrence (Buikstra and Ubelaker, 1994). However, its 
aetiology is multifactorial with several factors contributing to their formation, namely malnutrition, infectious diseases, intoxication, parasite infestation, metabolic disorders, childhood fevers, weaning problems, among others (Goodman and Rose, 1990; GuatelliSteinberg and Lukacs, 1999; Griffin and Donlon, 2009). Besides, regardless of the specific aetiology, enamel hypoplastic defects frequently result from a combination of one or more of the above-mentioned factors with normal physiological processes (Goodman and Rose, 1990). The consequence of that is that it is not possible to infer the exact nature of a stress event leading to its formation from the morphological analysis itself (Suckling, 1989).

In the osteoarchaeological literature, enamel hypoplasia have been widely used for intra and/or interpopulation comparisons, allowing for the identification of differences among social groups, subsistence strategies, health status, sequels of contact/conquest/occupation, and nutritional deficiencies of past populations (Rose et al., 1978; Goodman et al., 1980; Goodman and Rose, 1990; Malville, 1997; Santos and Coimbra, 1999; Lukacs et al., 2001; Palubeckaité et al., 2002; King et al., 2005; Griffin and Donlon, 2009; Minozzi et al., 2020). Although the study of health status using skeletal samples has been questioned by some researchers, a phenomenon called "osteological paradox" (Wood et al., 1992), the results reported by numerous studies support the idea that the potential error related to the interpretations based on the osteological remains is not as large as Wood et al. (1992) claimed (Larsen, 1987; Saunders and Hoppa, 1993). When LEH prevalence was compared in advantaged and disadvantaged samples, more defects were found in the groups suffering from compromised health (Bennike et al., 2005).

With the aim of recording changes in health status during development of the African enslaved individuals recovered from Valle da Gafaria, Lagos, Portugal $\left(15^{\text {th }}-17^{\text {th }}\right.$ centuries $)$, enamel hypoplasia's frequency, distribution and age of occurrence were investigated in a relatively large sample of individuals with permanent anterior teeth. 
During the Portuguese maritime expansion, the human slave trade was very common. At the beginning of the $15^{\text {th }}$ century, the harbour of Lagos (in the south of Portugal) played a central role given that it was from this location that vessels sailed to Africa and returned loaded with goods to the Kingdom of Portugal (Caldeira, 2013, 2017). In 2009, an excavation implemented outside the medieval walls of Lagos, a place known as Valle da Gafaria, allowed for the recovery of the skeletal remains of 158 individuals buried in a dump used during the $15^{\text {th }}-17^{\text {th }}$ centuries. As thoroughly discussed in previous studies, different types of data, namely archaeological, anthropological and historical, favour the idea that they were African enslaved individuals (Neves et al., 2011; Wasterlain et al., 2016; Coelho et al., 2017; Ferreira et al., 2019). These people were probably of different ethnicities. They would have been captured in the inland areas of sub-Saharan Africa, bought by the Portuguese in the West African coast (mainly from the current Mauritania to the Gulf of Guinea), shipped in several locations, and brought to the Lagos harbour (Fonseca, 2010; Caldeira, 2013). Nowadays, their skeletal remains, recovered in Valle da Gafaria, give us the opportunity to know more about their lives and, more specifically, their health status during development.

\section{Material and methods}

For this research, a sample of 78 individuals belonging to the Valle da Gafaria's skeletal assemblage (Lagos, Portugal) was analysed. All individuals aged more than 12 years old with at least one observable anterior tooth for dental hypoplasia were included in the study.

The age-at-death estimation was based on dental development (i.e., the sequence of formation and eruption of teeth, following Ubelaker, 1989), the fusion of the medial end of the clavicle and iliac crest (Webb and Suchey, 1985), the morphologic changes in the pubic symphysis (Brooks and Suchey, 1990) and in the auricular surface (Buckberry and 
Chamberlain, 2002) of the iliac bones. Afterwards, the individuals were assigned to four agegroups (12-19 years, 20-29 years, 30-39 years, $40+$ years).

For sex estimation, both metric and morphological analyses were adopted. In the scapula, the height and breadth of the glenoid cavity were measured in order to apply Macaluso (2011). In the humerus, the vertical diameter of the head and the epicondylar breadth were taken for Steyn and İşcan (1999) method. In the femur, the vertical and transverse diameters of the heads, the minimum vertical neck diameter, the anteroposterior and transverse subtrochanteric diameters were measured to apply Asala (2001) and Asala et al. (2004) methods. The iliac bones were analysed according to Phenice (1969) and Buikstra and Ubelaker (1994). Several other data were taken into account, namely: the results obtained through the application of the DSP metric analysis to the iliac bone (Murail et al., 2005) and the morphological approach of Bruzek (2002); the genetic profile of two individuals (65 and 166) made by Martiniano et al. (2014); and the assessment made by the last author (MTF) after observing the whole postcranial skeleton. Finally, all these results were taken into consideration by using a majority vote model, where each vote for either one of three options ("female", "male", or "unknown") was the final result of each method (for further details regarding sex and age-at-death estimation, please refer to Ferreira et al., 2018).

Although 744 anterior teeth were present, 97 (13.0\%) were excluded from the analysis due to dental calculus, tooth wear or intentional modifications. The remaining 647 teeth were observed, under good lighting conditions with the aid of a low-power microscope when necessary. Enamel hypoplastic defects were macroscopically observed on incisors and canines, being classified as pit-type, plane-type or furrow-type according to Berten (1895), and Hillson and Bond (1997). However, for the purpose of this study, only furrow-type defects (linear enamel hypoplasia or LEH) were analysed. Defect presence was identified on the labial/buccal surface, in ten segments of equal height from the occlusal edge to cemento- 
enamel junction with the aid of a graduated probe and following the visual map of the anterior dentition developed by Reid and Dean (2006) for a southern African population. This method allows to judge the age of onset for each defect observed.

In the Reid and Dean's method, the ages associated with each decile are clearly defined, but the ages at which enamel forms within each decile are not. In order to surpass this problem, Martin et al. (2008) used an interpolation to produce estimated ages at defect formation. However, according to these authors, this procedure introduces subjective bias into hypoplastic defect formation estimates. Therefore, in the present study, the same procedure as the one adopted by Łukasik and Krenz-Niedbała (2014) was used, i.e., all defects observed on all affected teeth in each individual, irrespective whether they represented the same chronological unit or not, were included in the analysis. However, considering that antimeres are expected to have lines in the same locations if the growth disruption is systemic, hypoplastic defects were matched across antimeric teeth within each individual. The statistical significance of the recorded values was tested with independent samples chi-square, by using the IBM SPSS statistics® program (version 22.0).

\section{Results}

Of the 78 individuals, $60.3 \%(n=47)$ were females, and $24.4 \%(n=19)$ were males. In 12 individuals (15.4\%), it was not possible to estimate sex (Table 1). The most numerous were middle adults, $30-39$ years (37.2\%), followed by young adults, $20-29$ years $(28.2 \%)$, then adolescents, $12-19$ years (24.4\%), and old adults, $\geq 40$ years $(5.1 \%)$. In $5.1 \%$ of the individuals the high degree of fragmentation impaired the age-at-death estimation.

In all, $89.7 \%$ of the individuals had at least one LEH, and $82.1 \%$ had multiple LEH (Figure 1). Despite the greater number of females in this skeletal assemblage, the percentage 
of individuals affected by hypoplasia by sex was approximately the same $(89.5 \%$ males and $89.4 \%$ females) (Table 1$)$

Of the 647 observable teeth, $63.5 \%$ presented at least one defect. In Table 2, the frequencies of teeth affected by LEH by sex and age-group are presented. As verified in the analysis by individual, no significant differences were found between the sexes in per tooth analysis (men: $62.9 \%$ teeth affected; women: $65.0 \%$ teeth affected; Chi-square $=0.211$; $\mathrm{df}=$ $1 ; \mathrm{P}=0.646$ ). Regarding age-groups, higher frequencies were reported for the eldest (men: 84.6\%; women: $77.8 \%$ ), followed by the youngest age-group (men: $69.7 \%$; women: $80.0 \%$ ).

Table 3 shows the distribution of teeth affected by LEH in each dental category, in both the upper and lower teeth, by sex. As it can be observed, the frequency was relatively high: most teeth presented one or more defects. Overall, the lower canine $(75.0 \%)$ was the most sensitive tooth to enamel hypoplasia, followed by the upper lateral incisor (70.3\%). In total, 949 hypoplastic lines were recorded. The mean LEH number (ratio between number of events and teeth affected) was 2.3. Canines were again the tooth type that presented the highest values $($ lower $=2.7$; upper $=2.5)$.

In Table S1, detailed data is presented for each individual, namely observed and hypoplastic teeth, number of defects (excluding those present in antimeric teeth), observable time-range of growth, age range of defects, as well as age of peak calculated as the average age in their formation. Although the number of observed teeth varies from individual to individual, $73.1 \%$ of the individuals had over $50 \%$ of their observable teeth hypoplastic. Besides, some individuals presented a relatively high mean number of defects per tooth (sometimes exceeding 3). Overall, the period covered ranges from the second year of life until five years of age. Age of occurrence of the physiological stress ranged between 1.5 and 5.2 years of age, and the mean peak age was between 3.3 and 3.7 years. 


\section{Discussion}

In the present study, the frequency of developmental dental defects was investigated in a sample of individuals aged 12-40+ years old exhumed from the Valle da Gafaria, Lagos, Portugal $\left(15^{\text {th }}-17^{\text {th }}\right.$ centuries $)$. Given that previous studies in this skeletal assemblage strongly favour the idea that these were enslaved African individuals of the beginning of the Atlantic slave trade, the analysis of dental enamel defects, providing a permanent record of growth disturbances, arises as a pressing investigation.

In all, 78 individuals were included in the study. Although 744 anterior teeth were present, dental calculus, tooth wear or intentional modifications impaired the observation of LEH in 97 teeth, probably contributing to an underestimation of the LEH's frequency in this sample. Even so, a great number of individuals (89.7\%) and anterior teeth (63.5\%) presented at least one defect. No significant differences were found between the sexes neither in the per individual analysis nor in the per tooth analysis. In a previous study, in which Wasterlain et al. (2018) aimed to analyse the growth of 31 non-adult individuals from this same skeletal assemblage (not included in this study), it had been already found a relatively large percentage of individuals ( $70.0 \%$ of 30 observable for this parameter) exhibiting at least one enamel hypoplasia. The apparent discrepancy between the frequencies found for the two samples from the same skeletal assemblage can be due to the fact that the former one was composed by several individuals with deciduous dentition. In fact, the development of some regions of the anterior deciduous teeth, namely half of the enamel crown of the incisors and the top third of the canine, occurs mostly in uterus (Schour, 1936), a more protected environment, whereas the development of permanent teeth is more exposed to external factors (Bogin, 1999; Hoppa and FitzGerald, 1999). Besides, as already described by other authors (Witzel et al., 2006, 2008; Birch, 2012), several differences in tooth shape, speed of formation and other formation processes, contribute to the fewer number of linear defects in 
deciduous teeth. If this was the case, the two studies complement themselves in order to make evident the difficulties experienced by the Lagos's enslaved individuals during their lives. However, other potential causes for such discrepancy must be considered. Firstly, possible different environments and living conditions during childhood between buried individuals, as some non-adults could have been born in Portugal, and some in Africa, being differently exposed to stress events during prenatal and postnatal life, reflected in their deciduous and permanent teeth. The same relates to the adults. While these proportions are not known, as already mentioned, they still can contribute to the discrepancy in LEH frequencies. Secondly, the time span based on the stratigraphy of the dump is rather extensive, as it covers three centuries. Nevertheless, it is believed that the exhumed individuals are from the beginning of the slave trade, because from the moment the enslaved individuals began to be baptized between 1580 and 1600, 11.53\% of the baptisms in Lagos were of enslaved people (Fonseca and Sabóia, 2001-2002) - they would have a right to a Christian funeral, performed at the same cemeteries as the free people (Caldeira, 2017). Only enslaved individuals without baptism were discarded in a dump site outside the fortified perimeter of the city, relatively close to the harbour, since they were considered as damaged goods, just like broken ceramics (Tinhorão, 1997; Caldeira, 2017). In fact, the AMS C14 date already obtained for three skeletons from this assemblage support this belief (individual 169: $450 \pm 40 \mathrm{BP}$, Cal AD 1420-1480, Cal BP 540-470, Beta-276508; individual 25: $560 \pm 30$ BP Cal AD 1310-1360, Cal BP 640-590, and Cal AD 1385-1425, Cal BP 565-525, Beta-438015; and individual 114: $370 \pm 30$ BP, Cal AD 1445-1530, Cal BP 505-420, and Cal AD 1545-1635, Cal BP 4053015, Beta-434529) (Ferreira et al., 2019). However, it should not be ruled out the hypothesis that some individuals died before being baptized, for example, just before or after arriving to the kingdom, which would not be unprovable given the poor conditions aboard the ships (Caldeira, 2013; Marques, 2017). 
Regarding other studies on enslaved individuals, almost all report relatively high frequencies of dental enamel hypoplastic defects. That is the case for Handler and Corrucini (1983) for the sample from the Newton plantation, in Barbados, Blakey et al. (1994) for enslaved African Americans from Maryland and Virginia, and Blakey et al. (2009) for the New York African Burial Ground, which reported 98\%, 88.9\% and 70.8\% of individuals affected, respectively. The exception concerns to the remains of enslaved Africans exhumed from the Pretos Novos' cemetery, in Brazil (Cook et al., 2012), which presented relatively low frequencies of linear enamel hypoplastic defects. However, according to Cook et al. (2012), these results could be underestimated due to traditional oral hygiene practices, very common in this sample, which may have erased moderate hypoplastic defects.

As regards South Portuguese coeval series, data are scarce and incomplete. In a skeletal sample of 65 adult individuals exhumed from the parish cemetery of Santa Maria da Graça de Lagos $\left(14^{\text {th }}-18^{\text {th }}\right.$ centuries), the results provided were not in sufficient detail to allow direct comparisons (Costa et al., 2008). This is a general osteoarchaeological study and, in what dental hypoplasia concerns, it only presents a barely readable graph with frequencies of defects per tooth type. This graph apparently shows that these individuals had their anterior teeth, in general, less affected by LEH than the enslaved individuals recovered from the same city.

In the current investigation, the per tooth analysis revealed that the lower canines presented the highest frequency of LEH (75.0\%), followed by the upper lateral incisors $(70.3 \%)$ and the lower canine $(69.7 \%)$. These results are broadly in line with that reported by other authors (King et al., 2005; Griffin and Donlon, 2009; Minozzi et al., 2020). The different "susceptibility" of tooth classes has been interpreted as a difference in the resistance to disruption of ameloblasts at the various stages of their matrix secreting career, but also as a 
product of distinct geometries of crown growth (for further discussion, please refer to Hillson and Bond, 1997).

In several teeth, the observation of some enamel regions was hampered by intentional dental modifications, dental wear or calculus (Figure 2). Therefore, for each individual the observable time-range of growth according to the decile chart of anterior teeth enamel growth proposed by Reid and Dean $(2000,2006)$, is given. From Table S1, it is possible to see that despite the abovementioned problems, the areas of missing information in terms of time periods of growth that cannot be observed are not wide. Overall, the period covered ranges from the second year of life until five years of age, which, in fact, covers almost the entire chronological period provided by Reid and Dean (2006) data on anterior teeth. Regarding the age of occurrence of the stressful events, it ranged between 1.5 and 5.2 years, with peaks in LEH formation falling between 3.3 and 3.7 years. Even though for many individuals, the observable period of growth begins at 0.8 years, the earliest stress episodes occurred in these enslaved individuals only at 1.5 years of age. This and the fact that the peak in LEH formation for these individuals has been 3.3-3.7 years of age deserve particular attention. It can be related to the consequences of weaning, which is commonly associated with many adverse factors, such as loss of both nutrients and immunity provided by the mother's milk, poor quality of solid foods, poor sanitary conditions, among others (Hanson, 2007; Lukasik and Krenz-Niedbała, 2014). It should be borne in mind, however, that although weaning might be abrupt, it is usually a process that occurs over a period of time, not an event occurring at a precise time in a child's life (Martin et al., 2008). This is very important because while introducing complementary food to an infant's diet, the protective effect of breastfeeding is still provided (WHO, 2004). The critical moment for the child's health is therefore the complete discontinuation of breast feeding (Lukasik and Krenz-Niedbała, 2014). 
Inferences about weaning based on a peak in LEH formation should be complemented with additional sources, whenever possible. Although no historical data about the weaning age in enslaved African people from this time period was found, longer periods of breastfeeding were referred by other authors for the $19^{\text {th }}$ century African in comparison to their contemporaneous European populations (over 2 years of age vs. less than one year) (Klein and Engerman, 1978; Handler and Corruccini, 1983, 1986). Besides, for the sample of enslaved individuals from the Newton plantation, the modal age for LEH occurrence was between 3 and 4 years of age, very similar to the age span here obtained, which Handler and Corruccini (1983) interpreted as related to weaning. However, according to Blakey et al. (1994), weaning should not be the only factor considered to contribute to the high frequencies of LEH during the middle years of enamel development. In a sample of enslaved African Americans from the eighteen- and nineteenth century from Maryland and Virginia, they concluded that many kinds of physical stressors would have been felt by children. In addition to the problems of nutrition, hygiene and disease, the physical environment, namely workload and even clothing and housing, among others, should be considered important. In the Lagos case, despite not being possible to know how long these individuals lived in Portugal, the captivity in Lagos would be frequently characterized by unhygienic conditions, insufficient diet for slave mothers and children, and poor-inexistent medical care (Caldeira, 2013, 2017). Besides, enslaved children were ubiquitously used in a variety of roles, namely as domestic servants and as unskilled labour (Campbell et al., 2009; Caldeira, 2017), and therefore subjected to a workload not favourable to a normal growth and development. In fact, the results here presented also suggest that individuals continued to suffer from episodes of stress until a relatively late stage of childhood (5.2 years), probably long after weaning.

Interestingly, the already mentioned study by Wasterlain et al. (2018) has found that the nonadult individuals of this skeletal assemblage died more frequently in late stages of childhood 
(approximately between 7 and 9 years) which is relatively uncommon and point to a rather late critical period in growth.

In this study, the posterior teeth have not been examined. Future studies analysing LEH in second molars should shed light to the preceding year (6-7 years). While covering a later stage of infancy (9-11 years), third molars are frequently less reliable since they are often absent due to agenesis/impaction/late eruption. Also, Harris lines may bring some answers, having in mind the shortcomings of this stress marker (Beom et al., 2014). Such investigation will be very important considering that other studies of enslaved individuals have already reported stressful events, such as malnutrition or disease, during late childhood or late adolescence (Blakey et al., 2009; Fricke et al., 2020). In the case of a first generation enslaved African woman from Pietermaai, Curaçao (Netherlands Antilles), Fricke et al. (2020) even contemplate the hypothesis that these lesions could have been caused by a highly physically and psychologically stressful event such as forced passage to the Americas. In the Lagos case, the place where the individuals spent their childhood is uncertain, as well the conditions under which they grew. As above mentioned, what is known is that these enslaved individuals were probably captured in multiple locations from sub-Saharan Africa, bought and shipped by the Portuguese, and brought in different ages to the harbour of Lagos (Wasterlain et al., 2016, 2018; Coelho et al., 2017; Rufino et al., 2017). In fact, when the Portuguese arrived to Africa, a relatively large and complex network of slave trade was already established (N'Diaye, 2008; Caldeira, 2013, 2017; Marques, 2017). From the $8^{\text {th }}$ century, Muslim merchants had developed a large slave trade network originated in subSaharan Africa, that extended from Tanzania (in the east) to the coast of Senegal (in the west), but also to the south, to the forests (N'Diaye, 2008; Marques, 2017). This trade took place in very harsh and, at times, violent conditions (N'Diaye, 2008; Caldeira, 2013, 2017; Marques, 2017). In effect, Marques (2017) referred that the global mortality rate in such 
Islamic trade would have varied between $10 \%$ and $25 \%$, values very similar to those reported for the later transatlantic trade.

Despite the interesting findings, this study presents some limitations that shall be taken into consideration:

Firstly, several studies have addressed the relationship between enamel microstructure and the macroscopic appearance of hypoplastic enamel defects, demonstrating that by using a microscopic analysis, additional information regarding the mechanisms underlying the formation of hypoplasia can be obtained (Goodman and Rose, 1990; Witzel et al., 2006, 2008; Hassett, 2014). Besides, macroscopic observation has been shown to 'miss' episodes of growth disruption due to the variable behaviour of enamel forming cells in response to growth disruption (Witzel et al., 2006, 2008), and depending on where they outcrop in developing enamel (Hassett, 2014). However, as also highlighted previously (Hassett, 2014), microscopic methods are rather expensive and inordinately time-consuming, which often hinders, or even prevents, their application, which was the case in the present study. Recognising, however, this important limitation of the current investigation, further microscopic studies are advised in the future.

Secondly, pre-molars and molars were not examined in this study, but given the results obtained, the possible 7-9 years' age range of increased mortality risk, and the fact that they are not intentionally modified, in the future, these teeth may provide valuable information for comparison. While not immediately covered by enamel formation, the preceding year (6-7 years) shall be observed in the second molars. Despite covering a later stage of infancy, third molars are frequently less reliable since they are often absent due to agenesis/impaction/late eruption. 
Thirdly, as above mentioned, it should be kept in mind that several conditions, namely dental calculus, tooth wear, intentional dental modifications, and tooth loss (ante and post mortem) may have contributed to an underestimation of the LEH's frequency in this sample.

Fourthly, it should not be forgotten that the histological studies carried out by Reid and Dean (2006) showed that the enamel defects formed prior to the first year of age are practically invisible on the crown surface, making this life period a mystery in what regards physiological stress.

Finally, despite that the obtained results reinforce the idea that the Lagos's individuals who survived until adulthood experienced harsh living conditions during childhood, it is not yet known the precise provenance of each individual, if he/she was born in Africa or Portugal, and for how long he/she lived in Lagos, etc. Further ancient DNA studies, isotopic analyses, and strontium isotope ratios should be performed in order to give information about the ethnicity of each Lagos's enslaved individual and the place of residence in the last years of life. Such information crossed with the data given by the LEH's timing of occurrence shall give a much more detailed and interesting picture of how this enslaved people lived and suffered.

\section{Acknowledgements}

The authors thank the Centre for Functional Ecology, Centro de Investigação em Antropologia e Saúde, and Grupo Dryas Octopetala. The co-author Sofia N. Wasterlain was financed by national funds by FCT - Fundação para a Ciência e Tecnologia, under the project with the reference FCT-PEst-OE/SADG/UI0283/2019. The co-author Liliana M. Carvalho was financed by FCT - Fundação para a Ciência e Tecnologia, under the project with the reference SFRH/BD/144136/2019. The co-author Maria Teresa Ferreira was financed by national funds by FCT - Fundação para a Ciência e Tecnologia, under the project with the 
reference UI0197-UID/BIA/04004/2020. The authors also acknowledge the anonymous reviewers whose valuable comments and suggestions allowed us to improve the manuscript. The authors state that they do not have any conflict of interest to declare.

\section{References}

Asala SA. 2001. Sex determination from the head of the femur of South African white and blacks. Forensic Science International 117: 15-22.

Asala SA, Bidmos MA, Dayal MR. 2004. Discriminant function sexing of fragmentary femur of South African blacks. Forensic Science International 145: 25-29.

Bennike P, Lewis ME, Schutkowski H, Valentin F. 2005. Comparison of child morbidity in two contrasting medieval cemeteries from Denmark. American Journal of Physical Anthropology 128: 734-746.

Beom J, Woo EJ, Lee IS, Kim MJ, Kim YS, Oh CS, Lee SS, Lim SB, Shin DH. 2014. Harris lines observed in human skeletons of Joseon Dynasty, Korea. Anatomy \& Cell Biology 47: $66-72$.

Berten J. 1895. Hypoplasien des Schmelzes (Congenitale Schmelzdefecte; Erosionen). Dt Mschr Zahnheilk 13, 425-439, 483-498, 533-548, 587-600.

Birch W. 2012. Incremental growth of deciduous tooth enamel. PhD Thesis in Philosophy. University College London: London.

Blakey ML, Leslie TE, Reidy JP. 1994. Frequency and chronological distribution of dental enamel hypoplasia in enslaved African Americans: a test of the weaning hypothesis. American Journal of Physical Anthropology 95: 371-383.

Blakey ML, Mack M, Barrett AR, Mahoney SS, Goodman AH. 2009. Childhood health and dental development. In Skeletal biology of the New York African Burial Ground, Part 1, Blakey ML, Rankin-Hill LM (eds.). Howard University Press: Washington, D.C.; 306-331. 
Bogin B. 1999. Patterns of human growth. $2^{\text {nd }}$ ed. Cambridge University Press: Cambridge.

Brooks S, Suchey JM. 1990. Skeletal age determination based on the os pubis: A comparison of the Acsádi-Nemeskéri and Suchey-Brooks methods. Journal of Human Evolution 5: 227-238.

Bruzek J. 2002. A method for visual determination of sex, using the human hip bone. American Journal of Physical Anthropology 117: 157-168.

Buckberry JL, Chamberlain AT. 2002. Age estimation from the auricular surface of the ilium: a revised method. American Journal of Physical Anthropology 119: 231-239.

Buikstra JE, Ubelaker DH. 1994. Standards for data collection from human skeletal remains. Arkansas Archaeological Survey Research Series: Arkansas.

Caldeira AM. 2013. Escravos e traficantes no Império Português: o comércio negreiro português no Atlântico durante os séculos XV a XIX. A Esfera dos Livros: Lisboa.

Caldeira AM. 2017. Escravos em Portugal, das origens ao século XIX. A Esfera dos Livros: Lisboa.

Campbell G, Miers S, Miller JC. 2009. Editors' introduction. In Children in Slavery through the Ages, Campbell G, Miers S, Miller JC (eds.). Ohio University Press: Athens; 115.

Coelho C, Navega D, Cunha E, Ferreira MT, Wasterlain SN. 2017. Ancestry estimation based on morphoscopic traits in a sample of African slaves from Lagos, Portugal (15th-17th centuries). International Journal of Osteoarchaeology 27: 320-326.

Commission on Oral Health Research and Epidemiology. 1982. An epidemiological index of developmental defects of dental enamel (DDE index). International Dental Journal 32: $159-167$. 
Cook DC, Bastos MQR, Lopes C, Mendonça de Souza S, Santos RV. 2012. Pretos Novos: Evidence for African oral hygiene practices in Brazil, 1769-1830. International Journal of Osteoarchaeology 25: 238-244.

Costa C, Santos S, Ferro S, Almeida P, Fernandes T. 2008. O cemitério paroquial de Santa Maria da Graça: estudo antropológico. In Entre muralhas e templos, a intervenção arqueológica no Largo de Santa Maria da Graça, Lagos (2004-2005), Díaz-Guardamino M, Morán E. (eds.). Câmara Municipal de Lagos: Lagos; 106-201.

Ferreira MT, Coelho C, Coelho JO, Navega D, Wasterlain SN. 2018. New data about sex and age-at-death based on the postcranial skeleton of the enslaved adult Africans found at Lagos, Portugal (15th-17th centuries). Cadernos do GEEvH 7: 7-16.

Ferreira MT, Coelho C, Wasterlain SN. 2019. Discarded in the trash: Burials of African enslaved individuals in Valle da Gafaria, Lagos, Portugal (15th-17th centuries). International Journal of Osteoarchaeology 29: 670-680.

Fonseca J. 2010. Escravos e Senhores na Lisboa quinhentista. Edições Colibri: Lisboa.

Fonseca J, Sabóia J. 2001-2002. Os Negros de Faro e a Confraria de Nossa Senhora do Rosário. Anais do Município de Faro 21-32: 112-131.

Fricke F, Laffoon J, Victorina A, Haviser J. 2020. Delayed physical development in a first generation enslaved African woman from Pietermaai, Curaçao. International Journal of Osteoarchaeology 30: 43-52.

Goodman AH, Rose J. 1990. Assessment of systemic physiological perturbations from dental enamel hypoplasias and associated histological structures. Yearbook of Physical Anthropology 33: 59-110.

Goodman AH, Armelagos GJ, Rose JC. 1980. Enamel hypoplasias as indicators of stress in Prehistoric populations from Illinois. Human Biology 52: 515-598. 
Griffin RC, Donlon D. 2009. Patterns in dental enamel hypoplasia by sex and age at death in two archaeological populations. Archives of Oral Biology 54S: S93-S100.

Guatelli-Steinberg D, Lukacs JR. 1999. Interpreting sex differences in enamel hypoplasia in human and non-human primates: developmental, environmental and cultural considerations. Yearbook of Physical Anthropology 42: 73-126.

Handler JS, Corruccini RS. 1983. Plantation slave life in Barbados: a physical anthropological analysis. Journal of Interdisciplinary History 14: 65-90.

Handler JS, Corruccini RS. 1986. Weaning among West Indian Slaves: Historical and Bioanthropological Evidence from Barbados. William and Mary Quarterly, Third Series 43: $111-117$

Hanson LA. 2007. Breast-feeding and immune function. Proceedings of the Nutrition Society 66: 384-396.

Hassett BR. 2014. Missing defects? A comparison of microscopic and macroscopic approaches t identifying linear enamel hypoplasia. American Journal of Physical Anthropology 153: 463-472.

Hillson S. 2005. Teeth. $2^{\text {nd }}$ ed. Cambridge University Press: Cambridge.

Hillson S, Bond S. 1997. Relationship of enamel hypoplasia to the pattern of tooth crown growth: a discussion. American Journal of Physical Anthropology 104: 89-103.

Hoppa RD, FitzGerald CM. 1999. From head to toe: integrating studies from bones and teeth in biological anthropology. In Human Growth in the Past: Studies from Bones and Teeth, Hoppa RD, FitzGerald CM (eds.). Cambridge University Press: Cambridge; 1-31. 
King T, Humphrey LT, Hillson S. 2005. Linear enamel hypoplasias as indicators of systemic physiological stress: evidence from two known age-at-death and sex populations from Postmedieval London. American Journal of Physical Anthropology 128: 547-559.

Klein HS, Engerman SL. 1978. Fertility differentials between slaves in the United States and the British West Indies: A note on lactation practices and their possible implications. William and Mary Quarterly, Third Series 35: 357-374.

Larsen CS. 1987. Biological interpretations of subsistence economy and behavior from human skeletal remains. Advances in Archaeological Method and Theory 10: 339-445.

Lukacs JR, Nelson GC, Walimbe SR. 2001. Enamel hypoplasia and childhood stress in Prehistory: new data from India and Southwest Asia. Journal of Archaeological Science 28: 1159-1169.

Łukasik S, Krenz-Niedbała M. 2014. Age of linear enamel hypoplasia formation based on Massler and colleagues' and Reid and Dean's standards in a Polish sample dated to $13^{\text {th }}$ $18^{\text {th }}$ century CE. HOMO - Journal of Comparative Human Biology 65: 296-310.

Macaluso PJ. 2011. Sex discrimination from the glenoid cavity in black South Africans: morphometric analysis of digital photographs. International Journal of Legal Medicine 125: 773-778.

Malville NJ. 1997. Enamel hypoplasia in ancestral Puebloan populations from Southwestern Colorado: I. Permanent dentition. American Journal of Physical Anthropology 102: $351-367$.

Marques JP. 2017. Escravatura, perguntas e respostas. Guerra e Paz: Lisboa. 
Martin S, Guatelli-Steinberg D, Sciulli PW, Walker PL. 2008. Brief communication: comparison of methods for estimating chronological age at linear enamel formation on anterior dentition. American Journal of Physical Anthropology 135: 362-365.

Martiniano R, Coelho C, Ferreira MT, Neves MJ, Pinhasi R, Bradley DG. 2014. Genetic Evidence of African Slavery at the Beginning of the Trans-Atlantic Slave Trade. Scientific Reports 4: 5994.

Minozzi S, Caldarini C, Pantano W, di Giannantonio S, Catalano P, Giuffra V. 2020. Enamel hypoplasia and health conditions through social status in the Roman Imperial Age (1st-3rd centuries, Rome, Italy). International Journal of Osteoarchaeology 30: 53-64.

Murail P, Bruzek J, Houët F, Cunha E. 2005. DSP: a tool for probabilistic sex diagnosis using worldwide variability in hip-bone measurements. Bulletins et Mémoires de la Société d'Anthropologie de Paris 17: 167-176.

N’Diaye T. 2008. O genocídio ocultado: Investigação histórica sobre o tráfico negreiro árabo-muçulmano. Gradiva: Lisboa.

Neves MJ, Almeida M, Ferreira MT. 2011. História de um arrabalde durante os séculos XV e XVI: “o poço dos negros” em Lagos (Algarve, Portugal) e o seu contributo para o estudo dos escravos africanos em Portugal. In A Herança do Infante, Matos AT, Costa JP (eds.). Câmara Municipal de Lagos: Lagos; 29-46.

Palubeckaité Z, Jankauskas R, Boldsen J. 2002. Enamel hypoplasia in Danish and Lithuanian Late Medieval/Early Modern samples: a possible reflection of child morbidity and mortality patterns. International Journal of Osteoarchaeology 12: 189-201.

Phenice TW. 1969. A newly developed visual method of sexing the os pubis. American Journal of Physical Anthropology 30: 297-301. 
Reid DJ, Dean MC. 2000. Brief communication: the timing of linear hypoplasias on human anterior teeth. American Journal of Physical Anthropology 113: 135-139.

Reid DJ, Dean MC. 2006. Variation in modern human enamel formation times. Journal of Human Evolution 50: 329-346.

Rose JC, Armelagos GJ, Lallo JW. 1978. Histological enamel indicator of childhood stress in prehistoric skeletal samples. American Journal of Physical Anthropology 49: 511516.

Rufino AI, Ferreira MT, Wasterlain SN. 2017. Periapical Lesions in Intentionally Modified Teeth in a Skeletal Sample of Enslaved Africans (Lagos, Portugal). International Journal of Osteoarchaeology 27: 288-297.

Santos RV, Coimbra CEA. 1999. Hardships of contact: enamel hypoplasias in TupiMondé Amerindians from the Brazilian Amazonia. American Journal of Physical Anthropology 109: 111-127.

Saunders SR, Hoppa DR. 1993. Growth deficit in survivors and non-survivors: biological mortality bias in sub-adult skeletal samples. Yearbook of Physical Anthropology 36: $127-151$.

Schour I. 1936. The neonatal line in enamel and dentin of the human deciduous teeth and first permanent molar. Journal of the American Dental Association 23: 1946-1955.

Skinner M, Goodman AH. 1992. Anthropological uses of developmental defects of enamel. In Skeletal biology of past peoples: research methods, Saunders SR, Katzenberg MA (eds.). Wiley-Liss: New York; 153-174.

Steyn M, İşcan MY. 1999. Osteometric variation in the humerus: sexual dimorphism in South Africa. Forensic Science International 106: 77-85. 
Suckling G. 1989. Developmental defects of enamel - historical and present-days perspective of their pathogenesis. Advances in Dental Research 3: 87-94.

Tinhorão JR. 1997. Os Negros em Portugal: uma presença silenciosa, $2^{\text {nd }}$ ed. Editorial Caminho: Lisboa.

Ubelaker DH. 1989. Human skeletal remains: excavation, analysis and interpretation. $2^{\text {nd }}$ ed. Taraxacum: Washington.

Wasterlain SN, Neves MJ, Ferreira MT. 2016. Dental modifications in a skeletal sample of enslaved Africans found at Lagos (Portugal). International Journal of Osteoarchaeology 26: 621-632.

Wasterlain SN, Costa A, Ferreira MT. 2018. Growth faltering in a skeletal sample of enslaved nonadult Africans found at Lagos, Portugal $\left(15^{\text {th }}-17^{\text {th }}\right.$ centuries). International Journal of Osteoarchaeology 28: 162-169.

Webb PAO, Suchey JM. 1985. Epiphyseal union of the anterior iliac crest and medial clavicle in a modern multiracial sample of American males and females. American Journal of Physical Anthropology 68: 457-466.

WHO. 2004. Guiding principles for feeding infants and young children during emergencies. Geneva. http://whqlibdoc.who.int/hq/2004/9241546069.pdf

Wood JW, Milner GR, Harpending HC, Weiss KM. 1992. The osteological paradox: problems of inferring prehistoric health from skeletal samples. Current Anthropology 33: $343-370$.

Witzel C, Kierdorf U, Dobney K, Ervynck A, Vanpoucke S, Kierdorf H. 2006. Reconstructing impairment of secretory ameloblast function in porcine teeth by analysis of morphological alterations in dental enamel. Journal of Anatomy 209: 93-110. 
Witzel C, Kierdorf U, Schultz M, Kierdorf H. 2008. Insights from the inside: histological analysis of abnormal enamel microstructure associated with hypoplastic enamel defects in human teeth. American Journal of Physical Anthropology 136: 400-414.

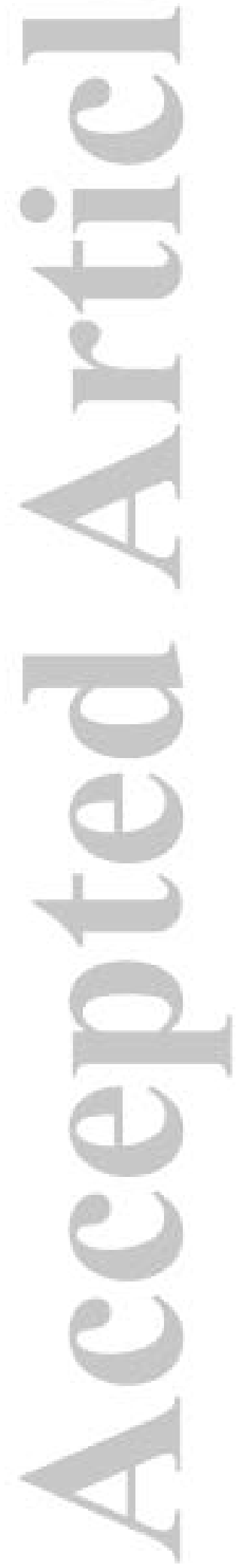


Table 1. Number and percentage of individuals from the Valle da Gafaria (Lagos, Portugal) with LEH by sex and age-group.

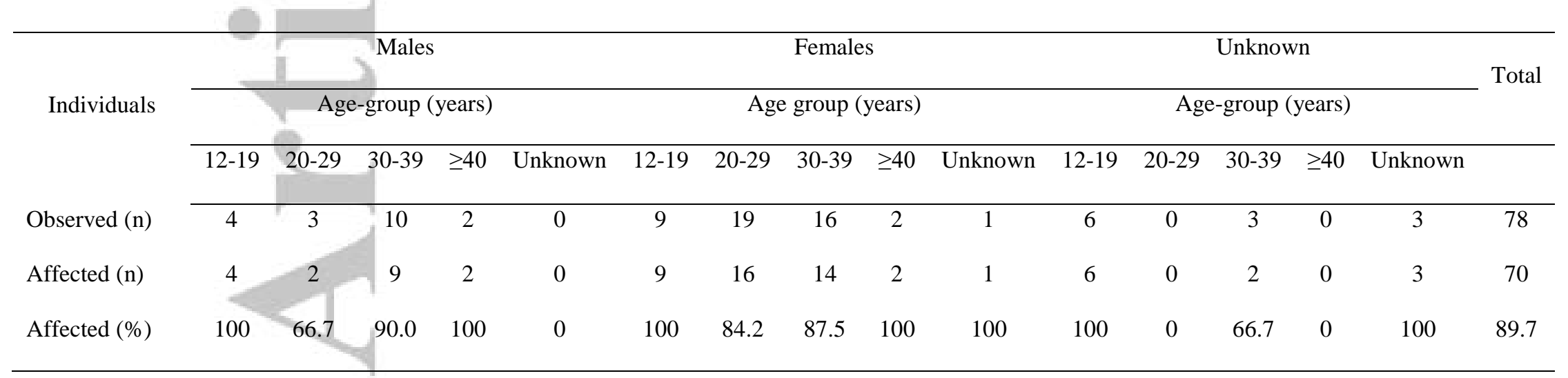


Table 2. Number and percentage of anterior teeth from the Valle da Gafaria (Lagos, Portugal) with LEH by sex and age-group.

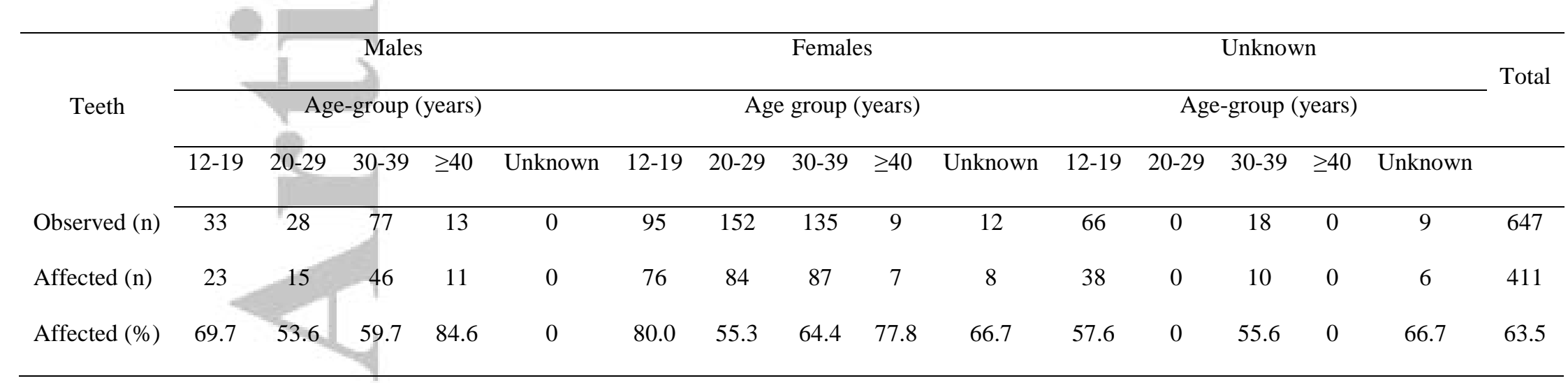


Table 3. Distribution of LEH in each dental category in a sample of anterior teeth from the Valle da Gafaria's individuals (Lagos, Portugal) by sex.

\begin{tabular}{|c|c|c|c|c|c|c|c|c|c|}
\hline \multirow{2}{*}{ Sex } & & \multicolumn{4}{|c|}{ Upper } & \multicolumn{4}{|c|}{ Lower } \\
\hline & & I1 & $\mathrm{I} 2$ & $\mathrm{C}$ & Total & I1 & I2 & $\mathrm{C}$ & Total \\
\hline \multirow[t]{4}{*}{ Males } & Teeth observed (n) & 21 & 24 & 28 & 73 & 20 & 26 & 32 & 78 \\
\hline & Teeth affected (n) & 10 & 17 & 20 & 47 & 8 & 16 & 24 & 48 \\
\hline & Teeth affected $(\%)$ & 47.6 & 70.8 & 71.4 & 64.4 & 40.0 & 61.5 & 75.0 & 61.5 \\
\hline & LEH (n) & 26 & 42 & 62 & 130 & 11 & 27 & 73 & 111 \\
\hline \multirow[t]{4}{*}{ Females } & Teeth observed (n & 53 & 59 & 76 & 188 & 54 & 76 & 85 & 215 \\
\hline & Teeth affecte & 38 & 44 & 52 & 134 & 23 & 40 & 65 & 128 \\
\hline & Teeth affected $(\%)$ & 71.7 & 74.6 & 68.4 & 71.3 & 42.6 & 52.6 & 76.5 & 59.5 \\
\hline & LEH (n) & 100 & 97 & 125 & 322 & 35 & 82 & 165 & 282 \\
\hline \multirow[t]{4}{*}{ Unknown } & Teeth observec & 16 & 18 & 18 & 52 & 14 & 12 & 15 & 41 \\
\hline & Teeth affected (n) & 13 & 10 & 13 & 36 & 3 & 5 & 10 & 18 \\
\hline & Teeth affected & 81.2 & 55.6 & 72.2 & 69.2 & 21.4 & 41.7 & 66.7 & 43.9 \\
\hline & LEH (n) & 18 & 20 & 22 & 60 & 10 & 7 & 27 & 44 \\
\hline
\end{tabular}




\begin{tabular}{|c|c|c|c|c|c|c|c|c|c|}
\hline \multirow[t]{4}{*}{ Total } & Teeth observed (n) & 90 & 101 & 122 & 313 & 88 & 114 & 132 & 334 \\
\hline & Teeth affected (n) & 61 & 71 & 85 & 217 & 34 & 61 & 99 & 194 \\
\hline & Teeth affected (\%) & 67.8 & 70.3 & 69.7 & 69.3 & 38.6 & 53.5 & 75.0 & 58.1 \\
\hline & LEH (n) & 144 & 159 & 209 & 512 & 56 & 116 & 265 & 437 \\
\hline
\end{tabular}




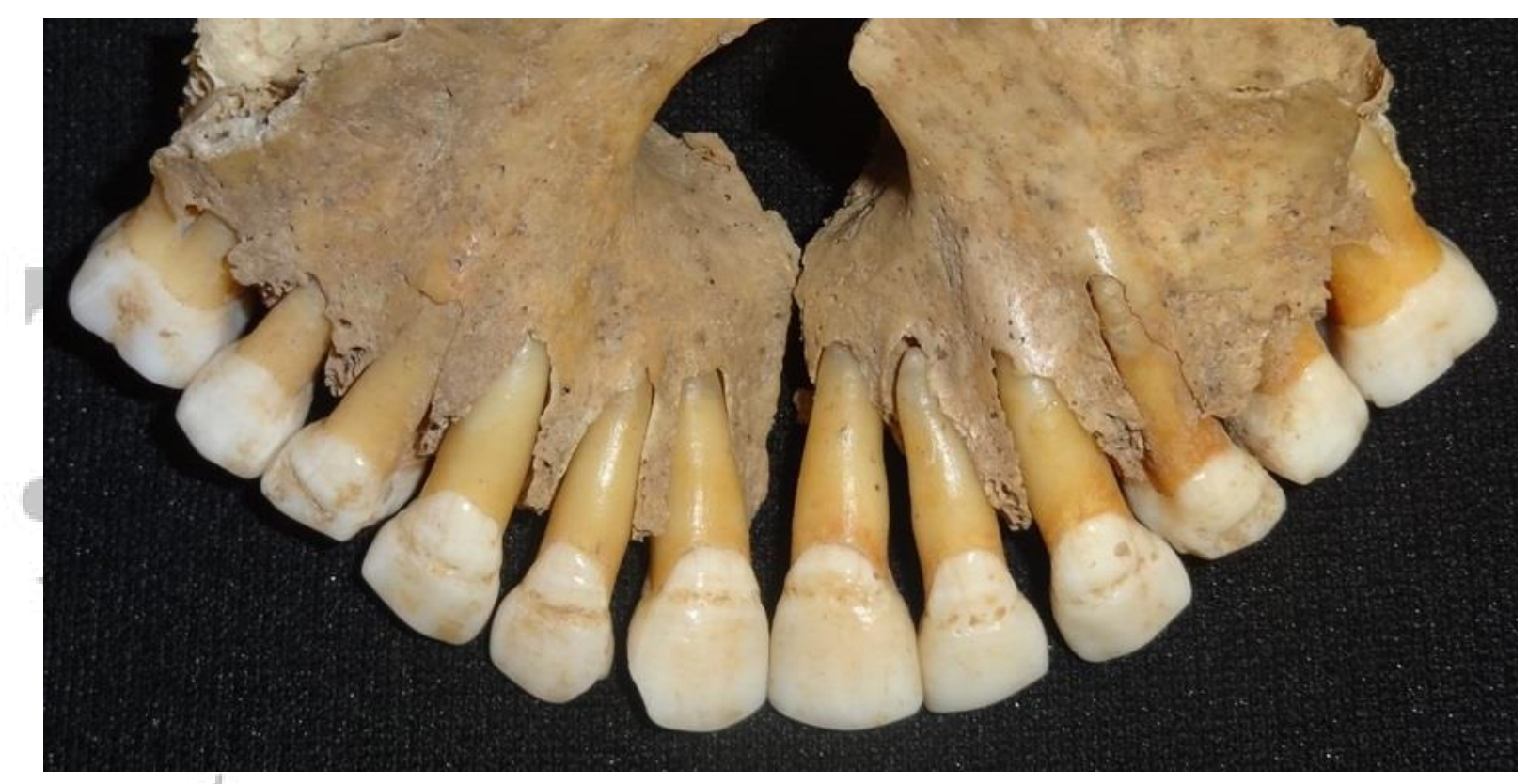

Figure 1. Maxilla (anterior view) of the individual no.154 from the deposit of urban waste of the Valle da Gafaria (Lagos, Portugal), with LEH in all upper incisors and canines.

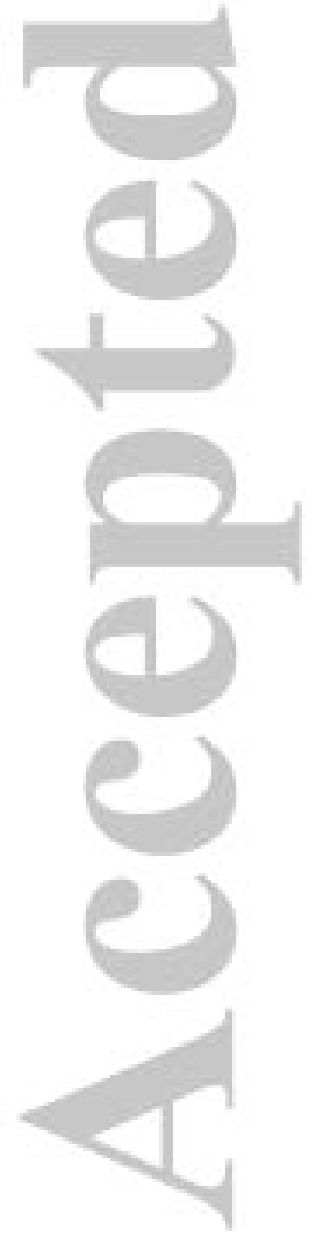

This article is protected by copyright. All rights reserved. 


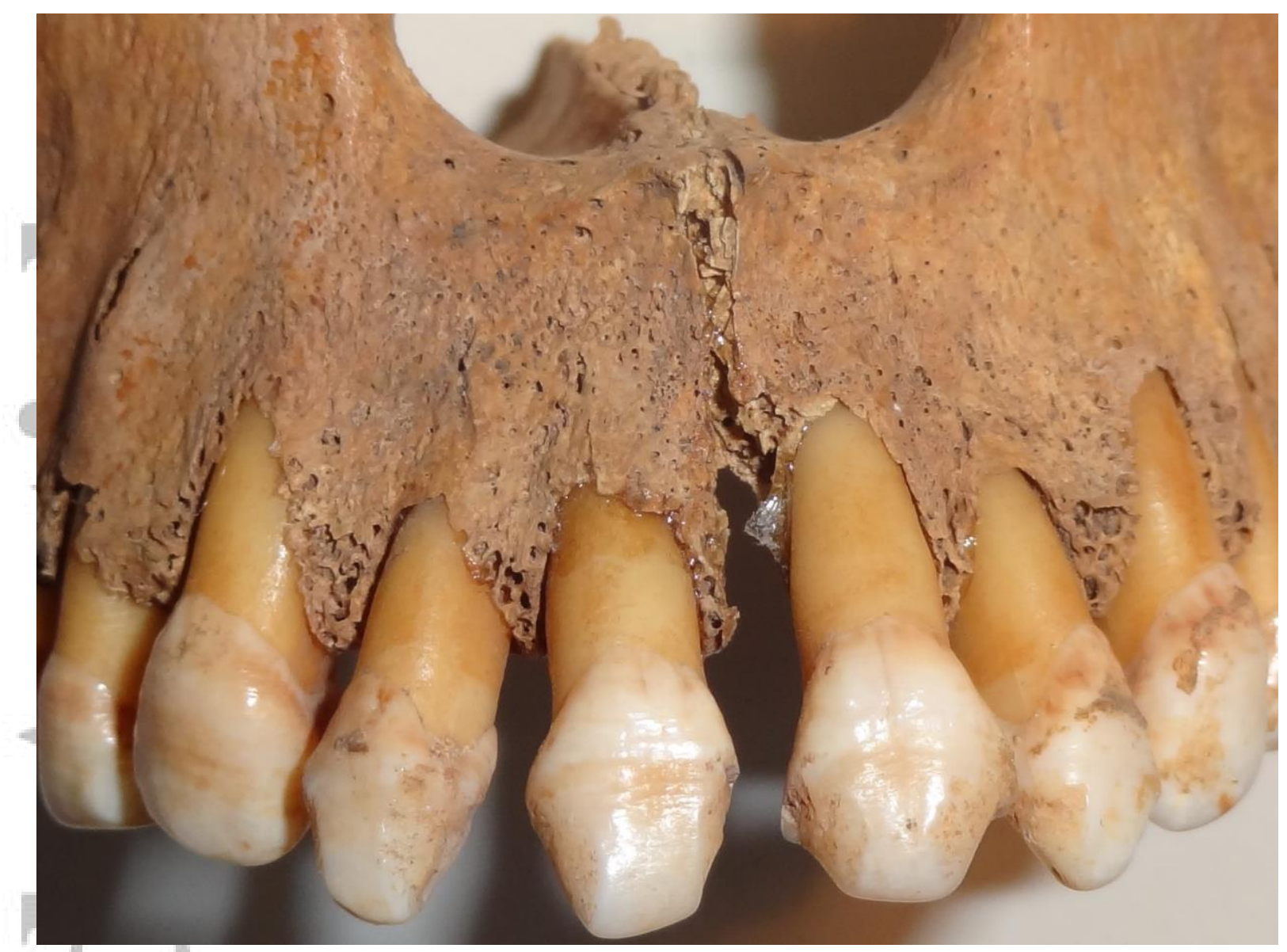

Figure 2. Maxilla (anterior view) of the individual no.159 from the deposit of urban waste of the Valle da Gafaria (Lagos, Portugal), with all upper incisors intentionally modified and therefore hampering LEH observation.

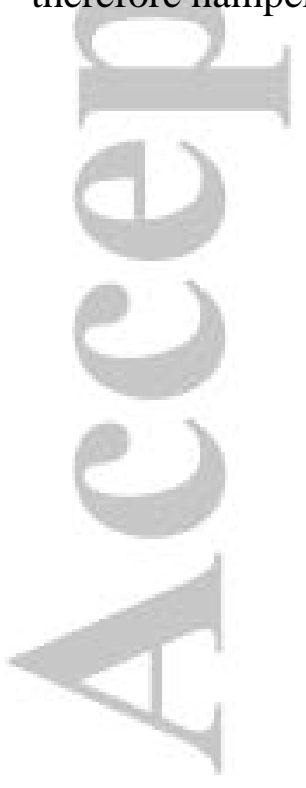

This article is protected by copyright. All rights reserved. 